\title{
TЕРМIHОЗНАВСТВО
}

УДК 811.161 .2

Ю. В. Бугаєвська

\section{ПРОФЕСІЙНА МОВЛЕННЕВА ДІЯЛЬНІСТЬ МАЙБУТНІХ ФАХІВЦІВ ЕКОНОМІЧНОГО ПРОФІЛЮ}

Для досягнення лінгводидактичних цілей викладачеві української мови треба вдосконалювати знання специфіки матеріалу (економічної термінології), якому він буде навчати. Терміни входять до продуктивного словникового запасу студентів для формування і формулювання думок у професійному контексті, а ступінь володіння термінологією визначається рівнем комунікативної компетенції.

Ключові слова: економічна термінологія, комунікативна компетенція, спілкування між фахівцями, комунікативно-орієнтований підхід.

Buhaievska Ju. V. Professional Communication of Prospective Specialists in the Field of Economics. The article emphasizes the importance of improving by a Ukrainian language teacher the knowledge of the specifics of educational material (economics terminology) to be taught, in order to achieve the linguistic and educational objectives set. The role of terms that should be included in the productive vocabulary of students to form and formulate thoughts in the professional context has been defined. It is noticed that the degree of proficiency in using terminology is determined by the level of communicative competence.

The aim of the article is to study different points of view on the problem of students' readiness to mastering language means that are necessary for establishing mutual understanding among communicators during joint professional activities. The task is to consider issues related to the communication aspect of the educational material that is presented by modern economic terms concentrated in texts of coursebooks for economics.

Economics vocabulary, which includes the names of phenomena and concepts of social and ideological spheres, is the part of the lexical system of the language the study of which is relevant, therefore, during activities of a teacher associated with training students to use economics terms, it is necessary to define and create conditions for obtaining necessary information of a professional character and ensuring effective communication among specialists in the relevant field.

Thus, teaching terminology within the framework of a communication-based approach is directly related to the development of verbal behavior which models situations of professional activity and its specific manifestations. Terms express special concepts that have been learnt by students, i.e., those which they easily and actively use when the need arises. The function of terms is in creating the professional component of information, forming a certain expression.

The prospect of the study is the organization of educational material and methodical developments for use based on the motives and peculiarities of student groups.

Key words: economics terminology, communicative competence, communication among specialists, communication-based approach.

\section{Ветуп}

Процес формування професійної компетенції студентів технічних вишів вимагає системного підходу до засвоєння мови спеціальності, основу якого становить оволодіння термінологічною лексикою і фразеологією, уміннями й навичками роботи з науковими текстами економічної тематики, 
професійне спілкування в аудиторії та за ії межами. Терміни і терміносполучення в текстах мають бути об'єктами розумової та мовленнєвої діяльності. Методику навчання термінології необхідно розглядати в усіх мовних аспектах і всіх видах мовленнєвої діяльності.

Метою статті $є$ вивчення різних точок зору на проблему готовності студентів до володіння мовленнєвими засобами, що необхідні для взаєморозуміння між комунікаторами під час спільної фахової діяльності. Завданням $€$ розгляд питань, пов'язаних з комунікативною спрямованістю матеріалу навчання, яким є сучасна економічна термінологія, зосереджена в текстах підручників з економічних спеціальностей.

Економічна лексика, що включає в себе найменування явищ і понять соціальної та світоглядної сфер, $є$ актуальною для вивчення частиною лексичної системи мови, тому під час навчання студентів економічній термінології важливим є визначення та проектування умов отримання необхідної інформації професійного характеру та повноцінного спілкування між фахівцями відповідного профілю.

\section{Виклад основного матеріалу дослідження}

Багато наукових досліджень (О. М. Шевченко, І. Г. Смирнова, О. І. Зайцева) присвячено поняттю інформаційно-комунікативної компетентності, що розуміємо як уміння ефективно вирішувати навчальні та професійні задачі, знання норм побудови ділової та міжособистісної комунікації з партнерами. Науковець Н. М. Лашук вважає, що в сучасному інформаційно-освітньому середовищі студенти і викладачі постають перед проблемою інформаційного вибору, а формування іншомовної комунікації визначає розвиток суспільства (Лашук, 2016).

Викладачі повинні мати певні відомості про тих, для кого призначені наукові тексти, про їхнє інформаційне навантаження, розташування за етапами навчання, і відповідно враховувати загальний обсяг знань та рівень спеціальних знань адресатів, щоб забезпечити адекватне розуміння змісту текстів.

Мовознавці Л. Р. Овчаренко, В. Д. Галкіна й ін. подають теоретичне обгрунтування змісту і структури іншомовної професійної компетентності та розглядають іiї як здатність студентів здійснювати комунікативну взаємодію, спираючись на комплекс специфічних мовленнєвих знань і навичок (Галкіна, 2014). На думку Ю. Г. Барабаш, формування соціокультурної компетенції студентів-економістів $є$ важливим складником комунікативної компетенції, адже міжкультурна комунікація в професійному середовищі можлива й успішна тільки в разі розуміння мовних особливостей представників різних культур (Барабаш, 2014).

Термінологічна лексика обмежена і сферою вживання, і семантичнонормативно, тому що є неекспресивною, зате вона не обмежена з погляду системних відображень словотворчих, формотворчих і семантичних відносин. Загалом пряме навчання поняттям завжди виявляється практично неможливим і неефективним, тому що викладач, який іде цим шляхом, не 
досягає нічого, крім механічного засвоєння слів. Деякі терміни мають певне стилістичне маркування і крім номінативної функції, можуть передавати додатковий національний, історичний, часовий, соціальний чи інші компоненти значення.

У спеціальних дослідженнях (О. О. Курок, Н. М. Бібік, І. В. Секрет) розглянуто головні теоретичні підходи до проблеми формування професійної компетентності майбутнього фахівця, проаналізовано визначення категорії компетентності в різних галузях знань, виділено інструментальні, міжособистісні компетенції професійної діяльності (Курок, 2017).

Принципами формування професійної комунікативної компетенції $\mathrm{\epsilon}$ мовна спрямованість навчального процесу, функціональний підхід до відбору термінологічного матеріалу, ситуативне уявлення про використання навчального матеріалу, а також поєднання комунікації та індивідуалізації. При цьому враховуються певні психолого-педагогічні аспекти, що вимагають конкретизації завдань навчання та посилення вимог до професіоналізму, тобто значимості професійної спрямованості змісту освіти.

Більшість науковців, серед яких М. М. Галицька, визнають, що поняття «компетентність» має дидактичну специфіку, і наголошують на компетентності як психологічному новоутворенні особистості, а під комунікативною компетентністю студентів 3ВО розуміють інтегральну якість особистості, яка синтезує в собі загальну культуру спілкування та її специфічні прояви в професійній діяльності (Галицька, 2015).

Відомий лінгвіст Г. П. Бондаренко вважає можливим створення на заняттях з української мови у ВТНЗ штучного мовленнєвого середовища для оволодіння термінологією, а правильно організовану роботу зі словниками такою, що сприяє поповненню термінологічного запасу студентів (Бондаренко, 2008). Для цього студентам треба засвоїти обсяг і зміст наукових понять, що позначаються термінами, мати уявлення про наукову поняттєву систему як таку, що відображає внутрішньотермінологічні зв’язки і відносини.

Погоджуємося з тезою (В. В. Чумак, Г. В. Барабанова), що запровадження ефективних технологій мовної освіти треба розглядати як забезпечення підготовки конкурентоспроможних фахівців, які здатні використовувати мовні ресурси для міжособистісної взаємодії, а однотипність навчальних дій студентів підвищує мотивацію оволодіння ними певним видом мовленнєвої діяльності (Барабанова, 2005).

Загальна характеристика вузькоспеціальної термінології, яка виявляється в порівнянні особливостей термінів, виділених теоретично, тобто з їхньої ідеальної функціональної природи, з одного боку, і фактичних правил вживання в спеціальних текстах, з іншого, також дає можливість побачити різноспрямовані процеси.

Серед педагогічних функцій викладача можна виокремити: комунікативну (теоретичне і практичне володіння комунікативним змістом навчального предмета, готовність викладача до користування цим матеріалом), інформаційну (відбір і передача потрібної для студентів інформації, 
яка відтворює реальну дійсність та дозволяє зрозуміти сферу призначення), мотиваційну (діяльність викладача, орієнтована на спрямування студента на активну навчальну взаємодію), функцію саморозвитку (викладач, виконуючи покладені на нього професійні обов'язки, удосконалює і себе).

\section{Висновок}

Таким чином, навчання термінології в рамках комунікативно-орієнтованого підходу безпосередньо пов'язано з відпрацюванням мовної поведінки, що моделює ситуації професійної діяльності та її специфічні прояви. Терміни висловлюють міцно засвоєні студентами спеціальні поняття, тобто ті поняття, якими вони вільно оперують і активно користуються при виникненні необхідності. Функція термінів - безпосередньо в утворенні професійного компоненту інформації, у формуванні певного висловлювання. Перспективою дослідження є організація навчального матеріалу та методичні розробки для використання з урахуванням мотивів та особливостей студентських груп.

\section{ЛІТЕРАТУРА:}

1. Барабанова Г.В. Методика навчання професійно-орієнтованого читання в немовному ВНЗ. Київ : ІНКОС, 2005. 315 с. 2. Барабаш Ю.Г. Соціокультурна направленість навчання іноземної мови студентів - майбутніх економістів. Педагогіка i психологія професійної освіти. 2014. № 4. С. 52-61. 3. Бондаренко Г.П. Система вправ 3 навчання російськомовних студентів-економістів української фахової термінології / URL: http://archive.nbuv.gov.ua/portal/soc_gum/Vmuvnz/2008_12/st12/08bonsis.pdf 4. Галкіна В.Д. Зміст і структура іншомовної професійної компетентності майбутніх магістрів військового управління. Вісник Національного університету оборони Украйни. 2014. Вип. 4. С. 24-29. 5. Галицька М. М. Складові комунікативної компетентності студентів вищих навчальних закладів. Освітологічний дискурс. 2015. № 2. С. 39-48. 6. Курок О.О. Формування професійної компетентності майбутніх економістів. Молодий вчений. 2017. № 3. С. 776-779. 7. Лашук Н. М. Іншомовна інформаційно-комунікативна компетентність майбутніх фахівців як складова професійної компетентності. Вісник Чернігівського наи. пед. університету. Серія: Пед. науки. 2016. Вип. 135. С. 96-99. 8. Словник-довідник з української лінгводидактики: навч. посібник. За ред. М.І. Пентилюк. Київ : Ленвіт, 2003. 149 с.

\section{REFERENCES}

1. Barabanova, H.V. (2005). Metodyka navchannia profesiino-oriientovanoho chytannia v nemovnomu VNZ [Methodology for teaching professionally-oriented reading in nonnative high schools]. K.: INKOS [in Ukrainian]. 2. Barabash, Yu.H. (2014). Sotsiokulturna napravlenist navchannia inozemnoi movy studentiv-maibutnikh ekonomistiv [Socio-cultural orientation of teaching foreign language students-future economists]. Pedahohika i psykholohiia profesiinoi osvity [in Ukrainian]. 3. Bondarenko, H.P. Systema vprav z navchannia rosiiskomovnykh studentiv-ekonomistiv ukrainskoi fakhovoi terminolohii [System of training exercises for Russian-speaking students-economists of Ukrainian professional terminology] / Retrieved from http://archive.nbuv.gov.ua/portal/soc_gum/Vmuvnz/2008_12/ st12/08bonsis.pdf 4. Halkina, V.D. (2014). Zmist i struktura inshomovnoi profesiinoi kompetentnosti maibutnikh mahistriv viiskovoho upravlinnia [Content and structure of foreign 
language professional competence of future masters of military management]. Visnyk Natsionalnoho universytetu oborony Ukrainy [in Ukrainian]. 5. Halytska, M.M. (2015). Skladovi komunikatyvnoi kompetentnosti studentiv vyshchykh navchalnykh zakladiv [Components of communicative competence of students of higher educational institutions]. Osvitolohichnyi dyskurs [in Ukrainian]. 6. Kurok, O.O. (2017). Formuvannia profesiinoi kompetentnosti maibutnikh ekonomistiv [Formation of professional competence of future economists]. Molodyi vchenyi [in Ukrainian]. 7. Lashuk, N.M. (2016). Inshomovna informatsiino-komunikatyvna kompetentnist maibutnikh fakhivtsiv yak skladova profesiinoi kompetentnosti [Foreign language informational and communicative competence of future specialists as a component of professional competence]. Visnyk Chernihivskoho pedahohichnoho universytetu. Seriia: Pedahohichni nauky [in Ukrainian]. 8. Pentyliuk, M.I. (2003). Slovnyk-dovidnyk z ukrainskoi linhvodydaktyky: navchalnyy posibnyk [Dictionary of Ukrainian linguistic editors: tutor manual]. K.: Lenvit [in Ukrainian].

Бугаєвська Юлія Володимирівна - кандидат педагогічних наук, доцент, доцент кафедри українознавства, Харківський національний автомобільно-дорожній університет; вул. Ярослава Мудрого, 25, Харків, 61002, Україна.

Tel.: +38-050-081-68-08

E-mail: bugaevskaylia@ukr.net

http://orcid.org/0000-0001-9982-8526

Buhaievska Juliia Volodymyrivna - PhD in Pedagogics, Associate Professor, Department of Ukrainian Studies, Kharkiv National Automobile and Highway University; Yaroslava Mudroho Str., 25, Kharkiv, 61002, Ukraine.

Надійшла до редакції 03 березня 2019 року 